\title{
Degeneration of the Amygdala/Piriform Cortex and Enhanced Fear/Anxiety Behaviors in Sodium Pump $\alpha 2$ Subunit (Atp1a2)-Deficient Mice
}

\author{
Keiko Ikeda, ${ }^{1}$ Tatsushi Onaka, ${ }^{2}$ Makoto Yamakado, ${ }^{3}$ Junichi Nakai, ${ }^{4}$ Tomo-o Ishikawa,,${ }^{5,6}$ Makoto M. Taketo, ${ }^{5,6}$ and \\ Kiyoshi Kawakami ${ }^{1}$ \\ Departments of ${ }^{1}$ Biology, ${ }^{2}$ Physiology, and ${ }^{3}$ Anatomy, Jichi Medical School, Kawachi, Tochigi 329-0498, Japan, ${ }^{4}$ Department of Information Physiology, \\ National Institute for Physiological Science, Okazaki 444-8585, Japan, ${ }^{5}$ Department of Pharmacology, Graduate School of Medicine, Kyoto University, \\ Sakyo, Kyoto 606-8501, Japan, and ${ }^{6}$ Banyu Tsukuba Research Institute (Merck), Tsukuba 300-2611, Japan
}

The sodium pump is the enzyme responsible for the maintenance of $\mathrm{Na}^{+}$and $\mathrm{K}^{+}$gradients across the cell membrane. Four isoforms of the catalytic $\alpha$ subunit have been identified, but their individual roles remain essentially unknown. To investigate the necessary functions of the $\alpha 2$ subunit in vivo, we generated and analyzed mice defective in the $\alpha 2$ subunit gene. Mice homozygous for the $\alpha 2$ mutation died just after birth and displayed selective neuronal apoptosis in the amygdala and piriform cortex. In these regions, high expression of c-Fos before apoptosis indicated neural hyperactivity, and re-uptake of glutamic acid and GABA into $\mathrm{P}_{2}$ fraction containing crude synaptosome was impaired. These results indicate that the $\alpha 2$ subunit plays a critical role regulating neural activity in the developing amygdala and piriform cortex. Further supporting a role of the $\alpha 2$ subunit in the function of the amygdala, heterozygous adult mice showed augmented fear/anxiety behaviors and enhanced neuronal activity in the amygdala and piriform cortex after conditioned fear stimuli.

Key words: amygdala; piriform cortex; knock-out mice; Na,K-ATPase; neurotransmitter uptake; fear-anxiety behavior

\section{Introduction}

The sodium pump $\left(\mathrm{Na}^{+}, \mathrm{K}^{+}\right.$-ATPase, EC 3.6.1.3) is an integral plasma membrane protein responsible for the ATP-dependent transport of $\mathrm{Na}^{+}$and $\mathrm{K}^{+}$across the membrane. This transport produces the ion gradients that are critical to maintain a resting membrane potential, osmotic balance, and cytosolic $\mathrm{pH}$, and for $\mathrm{Na}^{+}$-coupled transport of various ions, glucose, and amino acids across the membrane. The pump consists of $\alpha$ and $\beta$ subunits. The catalytic $\alpha$ subunit contains the binding sites for the cations, ATP, and cardiac glycosides (Lingrel and Kuntzweiler, 1994), whereas $\beta$ subunit is required for the structural and functional maturation of the $\alpha$ subunit (for review, see Geering, 2001). Genes encoding four $\alpha$ and three $\beta$ isoforms have been identified, yet the specific role of each isoform remains essentially unknown. Tissue-restricted expression of some isoforms suggests isoformspecific roles in cell physiology. In adult rats, the $\alpha 1$ subunit is ubiquitously expressed; the $\alpha 2$ subunit is expressed mainly in excitable tissues, i.e., brain, skeletal muscle, and heart; and the $\alpha 3$ subunit is expressed solely in neural and cardiac tissues (Shull et

Received Jan. 29, 2003; revised March 11, 2003; accepted March 17, 2003.

This work was supported by a grant from Takeda Science Foundation (K.I.), in part by grants from the Ministry of Education, Culture, Sports, Science and Technology, and Organization for Pharmaceutical Safety and Research, Japan (M.M.T.), and in part by the Research Grant for Cardiovascular Diseases (12C-5) (K.K.) from the Ministry of Health, Labor and Welfare. We thank Dr. K. Sweadner for anti- $\alpha 2$ antibody, Dr. S. J. Tapscott for critical reading of this manuscript, Dr. M. Mishina and Dr. K. Imoto for the helpful discussions, and S. Kamada, Y. Watanabe, M. Takiguchi, and H. Ohto for technical assistance. We also thank the anonymous reviewer for valuable comments to improve this manuscript.

Correspondence should be addressed to Dr. Kiyoshi Kawakami, Department of Biology, Jichi Medical School, Kawachi, Tochigi 329-0498, Japan. E-mail: kkawakam@jichi.ac.jp.

M. M. Taketo's and T. Ishikawa's present address: Department of Pharmacology, Graduate School of Medicine, Kyoto University, Sakyo, Kyoto 606-8501, Japan.

Copyright $\odot 2003$ Society for Neuroscience $\quad$ 0270-6474/03/234667-10\$15.00/0 al., 1986; Orlowski and Lingrel, 1988; Sweadner, 1989; Lingrel et al., 1990; Shamraj and Lingrel, 1994). Both the $\alpha 2$ and $\alpha 1$ subunits are broadly expressed in the mouse brain during early development [embryonic day (E) 9.5-10.5] and subsequently become expressed in more restricted regions of the brain, such as meninges, the neopallial cortex, and the intermediate ventricular zones of the cerebral cortex (Herrera et al., 1994).

A recent study suggested a specific role of the $\alpha 2$ subunit in regulating $\mathrm{Ca}^{2+}$ concentrations in cardiac myocytes of mice with a heterozygous disruption of this gene (James et al., 1999). We independently sought to examine a specific role of this molecule and constructed mice defective in the $\mathrm{Na}^{+}, \mathrm{K}^{+}$-ATPase $\alpha 2$ subunit gene (Atp1a2) to study the function of the $\alpha 2$ subunit in vivo. Here we show that the homozygous mutant embryos had impaired re-uptake of neurotransmitters, enhanced neural excitation, and cell death specifically in the amygdala and piriform cortex. Furthermore, heterozygous adult mice showed augmented fear/anxiety behaviors and enhanced neuronal activity in the amygdala and piriform cortex after conditioned fear stimuli, supporting a role for the $\alpha 2$ subunit in regulating neural activity.

\section{Materials and Methods}

Construction of Atp1a2 targeting vector and generation of mutant mice

Mouse genomic DNA containing exons 21 and 22 of the Atpla2 was isolated by screening a 129/Sv mouse genomic $\lambda$ FIXII library (Stratagene, La Jolla, CA) using a rat Atp1a2 cDNA probe [nucleotide positions 2381-3158 according to Shull et al. (1986)]. A $6.5 \mathrm{~kb}$ KpnI-SacI fragment containing exons 21 and 22 and another downstream fragment of $\sim 1 \mathrm{~kb}$ (SacI-SacI) were isolated and subcloned in pBlueScript KS (Stratagene). A PGKneobpA cassette (see neo in Fig. $1 A$ ) was inserted into an XhoI site, which was introduced in exon 21. The bacterial diphtheria toxin $\alpha$ subunit gene (see DTA in Fig. 
$1 A$ ) driven by the phosphoglycerate kinase I gene promoter was inserted at an upstream KpnI site. Embryonic stem (ES) cells (RW4 ES cell line) were electroporated with the linearized targeting vector as described (Oshima et al., 1995). G418-resistant ES clones were screened by PCR using primers 5'-GGTTTGTAGGCCATCCATTTCAACCCAGC-3' and 5'-GCCTGCTTGCCGAATATCATGGTGGAAAAT-3'. Homologous recombinant candidates were verified by Southern hybridization using a probe shown in Figure $1 \mathrm{~A}$. Chimeras were generated by injecting the recombinant ES cells into C57BL/6J blastocysts and transferred to multi-cross hybrid (CLEA Japan, Inc., Tokyo, Japan) foster mothers. Atp $1 a 2^{+1-}$ was backcrossed five to seven generations to the C57BL/6J. In every experiment, mice from each genotype were littermates and of isogenic genetic background. We also backcrossed the Atp1a2 knock-out mice to the 129/Sv strain and observed a similar phenotype. Microsomal fractions were prepared as described (Guillaume et al., 1989). McB2 (anti- $\alpha 2$ antibody used in Fig. $1 D$ ) was kindly provided by K. Sweadner (Massachusetts General Hospital) (Urayama et al., 1989), and an anti- $\alpha 1$ antibody was purchased from Upstate Biotechnology (Waltham, MA). Another Atp1a2 targeted mouse in which a PGKneobpA cassette was inserted just after the initiation codon showed similar phenotype of death soon after birth and overexpression of c-Fos in the amygdala and piriform cortex (data not shown).

\section{Analysis of spontaneous body movement in fetuses}

Immediately after cervical dislocation of the pregnant female mice, the uterus was taken out and placed onto a thermostatically controlled hot plate $\left(37^{\circ} \mathrm{C}\right)$. Fetus spontaneous body movements in the uterus (twitching of the trunk, forelimb or hindlimb movement, and head movement) were observed for $3 \mathrm{~min}$. For nociceptive response, the cesareandelivered fetus was placed onto a thermostatically controlled hot plate $\left(37^{\circ} \mathrm{C}\right)$ and pricked on the trunk with a 26 gauge needle, and trunk movements were observed.

\section{Diaphragm muscle membrane potential}

Phrenic-diaphragmatic nerve-muscle preparations were isolated from E18.5 ether-anesthetized embryos. Preparations were placed under a stereomicroscope (SZX12, Olympus Optical, Tokyo, Japan) equipped with a video-rate charged coupled device (CCD) camera (CCD72, MTI Instruments, Albany, NY) and bathed in Krebs' solution containing (in mM): $137 \mathrm{NaCl}, 2 \mathrm{KCl}, 5 \mathrm{CaCl}_{2}, 2 \mathrm{MgCl}_{2}, 0.25 \mathrm{NaH}_{2} \mathrm{PO}_{4}, 1$ HEPES, and 10 glucose, $\mathrm{pH} 7.4$ with $\mathrm{NaOH}$, bubbled with a $95 \% \mathrm{O}_{2} / 5 \% \mathrm{CO}_{2}$ gas mixture at $26^{\circ} \mathrm{C}$. Membrane potentials of diaphragmatic muscle were measured using an intracellular microelectrode filled with $3 \mathrm{M} \mathrm{KCl}$ (resistance $10-15 \mathrm{M} \Omega$ ). The electric signals were filtered by using Hum Bug (Quest Scientific, North Vancouver, BC), amplified by using Axoclamp-2A (Axon Instruments, Union City, CA) and a laboratorymade amplifier, and recorded with a data recorder (VR-10B; Instrutech, Port Washington, NY). The resting membrane potentials described in Results are the means of those of 15-20 muscle fibers from each mouse ( $n=4$ for the wild-type and the homozygote; $n=5$ for the heterozygote).

\section{Histological examination}

Embryos were obtained from timed pregnancies, with noon of the plug date defined as E0.5. Brains were fixed in $4 \%$ paraformaldehyde $/ 0.1 \mathrm{M}$ PBS. Paraffin-embedded sections (10 $\mu \mathrm{m}$ thick) were stained with Carazzi's hematoxylin and eosin (see Fig. $2 A-F$ ). Electron microscopy was performed using tissues fixed in $2 \%$ glutaraldehyde in $0.1 \mathrm{M}$ cacodylate buffer, $\mathrm{pH} 7.4$, incubated in $2 \% \mathrm{OsO}_{4} / \mathrm{PBS}$, dehydrated, and embedded in Epon. Ultrathin sections were analyzed at $100 \mathrm{kV}$ in a JEM-2000EX microscope (JEOL, Peabody, MA) as described previously (Hanaichi et al., 1986). Terminal deoxynucleotidyl transferase-mediated biotinylated UTP nick end labeling (TUNEL) analysis was performed according to the protocol provided by the manufacturer (NeuroTacs, Trevigen, Inc., Gaithersburg, MD). Immunohistochemistry for c-Fos protein was performed as described previously (Onaka and Yagi, 2001). c-Fos-positive cells in the "adult brain" were quantified as follows. At the level of bregma -0.8 to $-0.9 \mathrm{~mm}$, the amygdala and piriform were outlined as oval $(0.5$ $\left.\mathrm{mm}^{2}\right)$ and rectangular $\left(0.5 \mathrm{~mm}^{2}\right)$ regions, respectively, and the number of c-Fos-positive cells in these areas was counted. Data described in the legend for Figure 8 are the mean number of c-Fos-positive cells per section counted on three successive sections (30 $\mu \mathrm{m}$ thick). Quantifica- tion of c-Fos-positive cells in the "embryonic brain" was described in the legend of Table 2. For the preparation of the $\alpha 2$-specific subunit peptide antibody used for immunohistochemistry, a peptide (GREYSPAATTAENGGGKKKQ), which covers amino acids $6-25$ of the mouse $\alpha 2$ subunit protein, was synthesized and used for immunization of rabbits. Affinity purification of antibodies was performed by absorption on covalently linked peptide columns. Immunohistochemistry for the $\alpha 2$ subunit was performed with paraffin-embedded brain sections using an antigen retrieval method, as described by the manufacturer (DakoCytomation, Glostrup, Denmark) using affinity-purified $\alpha 2$ peptide antibody (1:400). As a control, we used rabbit IgG (equivalent protein concentration, $400 \mathrm{ng} / \mathrm{ml}$ ), which was purified by affinity chromatography on Protein A-Sepharose CL-4B (Amersham Biosciences, Uppsala, Sweden).

\section{Measurements of neurotransmitter contents in the whole brain}

Pregnant mice were killed by cervical dislocation, and E17.5-18.0 embryos were obtained by cesarean delivery. The brain was immediately removed from the decapitated embryo and sonicated in $500 \mu \mathrm{l}$ of a solution of $0.2 \mathrm{M}$ perchloric acid and $100 \mu \mathrm{m}$ EDTA. The homogenate was centrifuged at $20,000 \times g$ for $15 \mathrm{~min}$ at $0^{\circ} \mathrm{C}$. The supernatant was diluted to 500 -fold by $0.1 \mathrm{M} \mathrm{K}_{2} \mathrm{CO}_{3}-\mathrm{HCl}, \mathrm{pH} 9.5$, and filtered on a disposable syringe filter (cellulose acetate, $0.45 \mu \mathrm{m}$; DISMIC-3CP, Advantec, Tokyo, Japan). Glutamic acid and GABA content of the filtrate were measured by reversed-phase HPLC and fluorimetric detection after derivatization with $o$-phthaldialdehyde as described previously (Leng et al., 2001).

\section{Preparation of $P_{2}$ fraction and assay of neurotransmitter uptake}

The brain was immediately removed from the decapitated embryo and homogenized in an ice-cold sucrose buffer ( $0.32 \mathrm{~m}$ sucrose, 5 mM HEPES$\mathrm{NaOH}$, and 0.1 mm EDTA, pH 7.6) using a Potter glass homogenizer plus Teflon pestle by 15 strokes at $300 \mathrm{rpm}$. The crude homogenate was centrifuged at $1500 \times g$ for $10 \mathrm{~min}$ at $4^{\circ} \mathrm{C}$. The supernatant was then centrifuged at $12,000 \times g$ for $30 \mathrm{~min}$ at $4^{\circ} \mathrm{C}$. The membrane pellets $\left(\mathrm{P}_{2}\right)($ Gray and Whittaker, 1962) were resuspended in artificial CSF (aCSF) containing (in mM): $132 \mathrm{NaCl}, 3 \mathrm{KCl}, 2 \mathrm{CaCl}_{2}, 2 \mathrm{MgSO}_{4}, 1.2 \mathrm{NaH}_{2} \mathrm{PO}_{4}, 10$ HEPES-NaOH, and 10 glucose, pH 7.4, bubbled with $95 \% \mathrm{O}_{2} / 5 \% \mathrm{CO}_{2}$ gas mixture and used promptly. Uptake reaction was initiated after $5 \mathrm{~min}$ preincubation at $26^{\circ} \mathrm{C}$ in aCSF by adding $100 \mu \mathrm{l}$ of reaction mixture to $100 \mu \mathrm{l}$ of $\mathrm{P}_{2}$ fraction at a final concentration of $5 \mu \mathrm{M}\left[{ }^{3} \mathrm{H}\right]$ glutamic acid (Amersham Biosciences) or $1 \mu \mathrm{M}\left[{ }^{3} \mathrm{H}\right] \mathrm{GABA}$ (Amersham Biosciences). Samples were incubated for $3 \mathrm{~min}$ at $26^{\circ} \mathrm{C}$, and the reaction was terminated by filtration using GF/C filters (Whatman, Kent, UK). Filters were washed three times with $1 \mathrm{ml}$ of ice-cold aCSF, and the radioactivity of filters was quantified by a Beckman LS1800 scintillation counter (Beckman Coulter, Fullerton, CA). Uptake was normalized for protein content that was determined by protein assay kit (Bio-Rad, Hercules, CA). The mean protein concentration of the $\mathrm{P}_{2}$ fraction was $0.97 \pm 0.24 \mathrm{mg} / \mathrm{ml}$ $(n=5)$ for wild-type, $0.96 \pm 0.28 \mathrm{mg} / \mathrm{ml}(n=5)$ for homozygous, and $1.01 \pm 0.29 \mathrm{mg} / \mathrm{ml}(n=5)$ for heterozygous mice. Nonspecific uptake was estimated in parallel samples containing specific neurotransmitter transporter blockers: $30 \mu \mathrm{M}$ L-trans-2,4-pyrrolidine-dicarboxylic acid (PDC) (Tocris Cookson, Ellisville, MO) for glutamic acid uptake and 100 $\mu \mathrm{M} \quad \mathrm{N}$-(4,4-diphenyl-3-butenyl)-3-piperidine carboxylic acid (SKF 89976A) (Tocris Cookson) for GABA uptake. Nonspecific uptake was similar when determined using "modified aCSF" composed of choline chloride instead of sodium chloride. Specific uptake was obtained from total uptake (in the absence of the specific transporter blocker) minus nonspecific uptake (in the presence of the specific transporter blocker). Inhibition of specific uptake by $1 \mathrm{~mm}$ ouabain (Sigma, St. Louis, MO) was also monitored in parallel samples. "Relative uptake" was calculated as relative percentage of specific uptake of the wild-type mice in each set of experiments, which was set as 100. Littermates from five different mother mice for glutamic acid $(n=5)$ and six different mother mice for GABA $(n=6)$ were examined.

PDC is a glutamate transporter blocker that inhibits three different glutamate transporters of GLT-1, EAAC1, and less efficiently, GLAST. GLT-1 is expressed in glial cells and developing neurons. PDC inhibits 
the transport activity in cultured neurons prepared from embryonic rats, in cortical synaptosomes prepared from neonatal rats, and cultured astrocytes prepared from adult rats (for review, see Danbolt, 2001). SKF89976A, a derivative of nipecotic acid, is a potent and specific inhibitor of GABA transporter 1(GAT-1). GAT-1 is expressed both in neurons and glia in adult rats, as well as in the developing rat brain (for review, see Borden, 1996; Jursky and Nelson, 1996).

Preparation of cultured astrocyte, immunostaining, Western blot, and assay of neurotransmitter uptake into astrocytes

Primary cortical astrocytes cultures were prepared from brains of E16.517.5 embryos as described (Kawakami et al., 1993). The secondary cultures on 24-well tissue culture plates were grown in Minimum Essential Medium (Sigma) with $10 \%$ fetal bovine serum for $1-3 \mathrm{~d}$ and used for uptake assays. The cells on the plates consisted of $>95 \%$ flat polygonal astrocytes as confirmed by positive immunostaining with anti-glial fibrillary acidic protein (GFAP) antibody (DakoCytomation) (see Fig. 6A). The $30 \mu \mathrm{g}$ astrocyte microsomal fractions were subjected to immunoblot using anti- $\alpha 2$ subunit peptide antibody (1:2000) or anti- $\alpha 1$ antibody (1:2000). Glutamic acid and GABA uptake were measured as follows. Cells were washed twice with an assay buffer containing (in $\mathrm{mM}$ ): 124 $\mathrm{NaCl}, 4.6 \mathrm{KCl}, 1.2 \mathrm{CaCl}_{2}, 1.3 \mathrm{MgCl}_{2}, 0.42 \mathrm{KH}_{2} \mathrm{PO}_{4}, 26.7 \mathrm{NaHCO}_{3}, 10$ glucose, $\mathrm{pH} 7.4$, and incubated in the assay buffer for $30 \mathrm{~min}$ at $26^{\circ} \mathrm{C}$. Then, each culture well received $0.5 \mu \mathrm{Ci} / \mathrm{ml} \mathrm{L}-\left[{ }^{3} \mathrm{H}\right]$ glutamic acid (Amersham Biosciences) plus $40 \mu \mathrm{M}$ unlabeled glutamic acid or $0.5 \mu \mathrm{Ci} / \mathrm{ml}$ L- $\left[{ }^{3} \mathrm{H}\right] \mathrm{GABA}$ (Amersham Biosciences) plus $40 \mathrm{~nm}$ unlabeled GABA. Uptake was terminated by washing twice with ice-cold assay buffer after 3 min incubation and followed immediately by cell lysis in $0.5 \mathrm{~N} \mathrm{NaOH} /$ $0.05 \%$ sodium lauryl sulfate. Aliquots were taken for scintillation counting and for protein assay (BCA protein assay kit; Pierce, Rockford, IL) using bovine serum albumin standards. Assays were performed with and without specific blocker, i.e., $30 \mu \mathrm{M}$ PDC for glutamic acid uptake and 30 $\mu \mathrm{M}$ SKF 89976A for GABA uptake, and the blocker-inhibitable uptake was shown as specific uptake after normalization to the protein concentration. All experiments were performed in duplicate in the presence or absence of $1 \mathrm{~mm}$ ouabain (glutamic acid, $n=5$ for each genotype; GABA, $n=4$ for each genotype).

\section{Behavioral analysis}

Wild-type and heterozygous male mice ( $70-100 \mathrm{~d}$ old $)$ were used in these studies. Mice lived in a $12 \mathrm{hr}$ light/dark cycle (lights on between 7:30 A.M. and 7:30 P.M.); all behavioral observations were made during the dark phase (9:30 P.M.-2:00 A.M.). Room temperature was $23^{\circ}$ C. Food and water were available ad libitum. Mice were housed singly for 1 week before the behavioral experiments started.

Light/dark test. The light/dark box consisted of two compartments: an open box with a white frosted plastic floor (light) and a closed black box with a black frosted plastic floor (dark) $(30 \times 15 \times 15 \mathrm{~cm}$ each). The test commenced by placing the mouse in the black box. The time spent in the light and dark boxes was measured over a period of $10 \min (n=11$ for each genotype).

Open field test. To measure locomotor activity in a new environment, the mouse was placed in the center of a white acrylic cage $(50 \times 50 \times 40$ $\mathrm{cm}$ ), and locomotion activity was measured automatically over a period of 10 min using NIH Image software ( $n=16$ for each genotype).

Elevated-plus maze. The elevated-plus maze consisted of two open $(25 \times 5 \mathrm{~cm})$ and two enclosed arms of the same size with $15-\mathrm{cm}$-high transparent walls. The arms and central square were constructed of white plastic plates and elevated to a height of $50 \mathrm{~cm}$ above the floor. The mouse was placed on the central platform of the maze with its head facing the open arm. The frequency of entry to open and closed arms and the time spent in open arms were recorded during the 10 min test $(n=11$ for each genotype).

Contextual fear conditioning. Each mouse was placed in a test chamber $(15 \times 15 \times 40 \mathrm{~cm})$ and allowed to explore freely for $5 \mathrm{~min}$. A mild (1 sec, $0.5 \mathrm{~mA}$ ) foot shock (denoted "F" in Fig. $7 \mathrm{H}$ ) or no foot shock as a control (denoted "C"), was applied five times at an interval of $30 \mathrm{sec}$. Testing was conducted $24 \mathrm{hr}$ after conditioning in the same chamber. The test duration was $10 \mathrm{~min}$ for behavioral experiments and $30 \mathrm{~min}$ for c-Fos immu- nohistochemistry. Data acquisition, control of shocks, and data analysis were performed automatically. Images were captured at two frames per second. For each pair of successive frames, the amount of area (pixels) within which the mouse moved was measured. When this area was below a certain threshold (i.e., 10 pixels), the behavior was judged as "freezing." The optimal threshold (amount of pixels) used to judge freezing was determined by adjusting it to the amount of freezing measured by human observation. Freezing that lasted less than the defined time threshold (i.e., $1 \mathrm{sec}$ ) was not included in the analysis ( $n=8$ for each genotype). Sensitivity to foot shock was determined by placing each genotype of mice into the conditioning chamber and giving foot shocks of increasing amplitude $(0.1,0.15,0.2,0.25,0.3,0.4$, and $0.5 \mathrm{~mA})$. Thresholds for flinch, jump, and vocalization were not significantly different between wild-type and heterozygous mice ( $n=4$ for each genotype). Blood samples were obtained by decapitation immediately after conditioned fear stimuli. For c-Fos immunohistochemistry, mice were anesthetized with sodium pentobarbital $(0.25 \mathrm{gm} / \mathrm{kg}$ body weight $)$ and transcardially perfused with $4 \%$ paraformaldehyde in PBS at 90 min after conditioned fear stimuli.

Rota-rod test. The apparatus consisted of a bar $(3 \mathrm{~cm}$ in diameter $)$ that was subdivided into five compartments by disks (Rota-rod treadmill for mice 7650; Ugo basile, Varese, Italy). Five mice were tested simultaneously on the apparatus. The bar started to rotate at a speed of $4 \mathrm{rpm}$. The rotating speed was increased stepwise every $30 \mathrm{sec}$ at $8,12,16,20,24$, 28,32 , and $40 \mathrm{rpm}$. The integrity of motor coordination was assessed by the time to fall from the rod. Mice were habituated to the apparatus once per day for $4 \mathrm{~d}$ before testing $[n=6$ (wild-type mice) and $n=8$ (heterozygous mice)].

Measurement of spontaneous motor activity. Spontaneous motor activity in the home cage was monitored for $48 \mathrm{hr}$ by using the "Activity Sensor Unit for mouse system” (AS-TIME/Ver.1, O’Hara \& Co., Tokyo, Japan), which detects heat radiation from the mouse body.

\section{A}
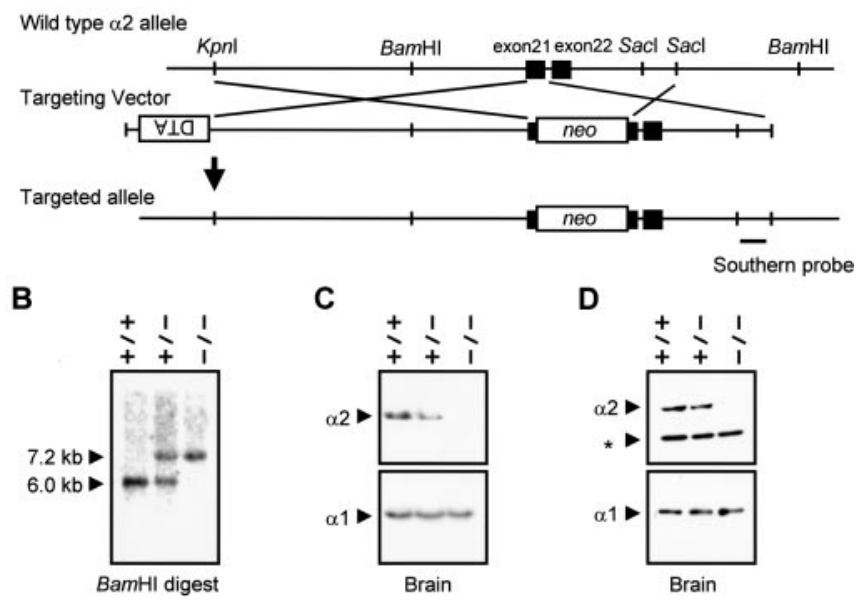

Figure 1. Targeting strategy for mutating the $\mathrm{Na}^{+}, \mathrm{K}^{+}$-ATPase $\alpha 2$ subunit gene (Atp1a2) and analyses of genomic DNA, $\mathrm{mRNA}$, and protein in wild-type, heterozygous, and homozygous mutant mice. A, A neomycin-resistant gene cassette (neo) was inserted in exon 21, and a DTA gene was inserted in the opposite orientation for negative selection. The targeted allele was verified by $P C R$ (data not shown) and Southern hybridization $(B)$ with the indicated probe. Positions of BamHI DNA fragments from the wild-type $(6.0 \mathrm{~kb})$ and targeted $(7.2 \mathrm{~kb})$ alleles are shown. C, Total RNA was isolated from the E18.5 brain, and $40 \mu \mathrm{g}$ of RNA was analyzed by Northern blotting with a Scal-Nhel fragment of the rat Atp 1a2 cDNA (Hara et al., 1987) (covering position 121- 497 of its (DNA, which corresponds to exons 2-5). As a control, the expression of the Atp1a1 ( $\mathrm{Na}^{+}, \mathrm{K}^{+}$-ATPase $\alpha 1$ subunit) gene is shown in a Northern blot using an $\mathrm{Ncol}$ fragment as a probe (Hara et al., 1987) (covering position 236-2435 of its (DNA). D, A microsomal fraction was prepared from the brains of E18.5 embryos, and $40 \mu \mathrm{g}$ of protein was analyzed by Western blotting with either an anti- $\alpha 2$ antibody (1:100, McB2) or an anti- $\alpha 1$ antibody (1:2000). The asterisk shows a nonspecific band. 

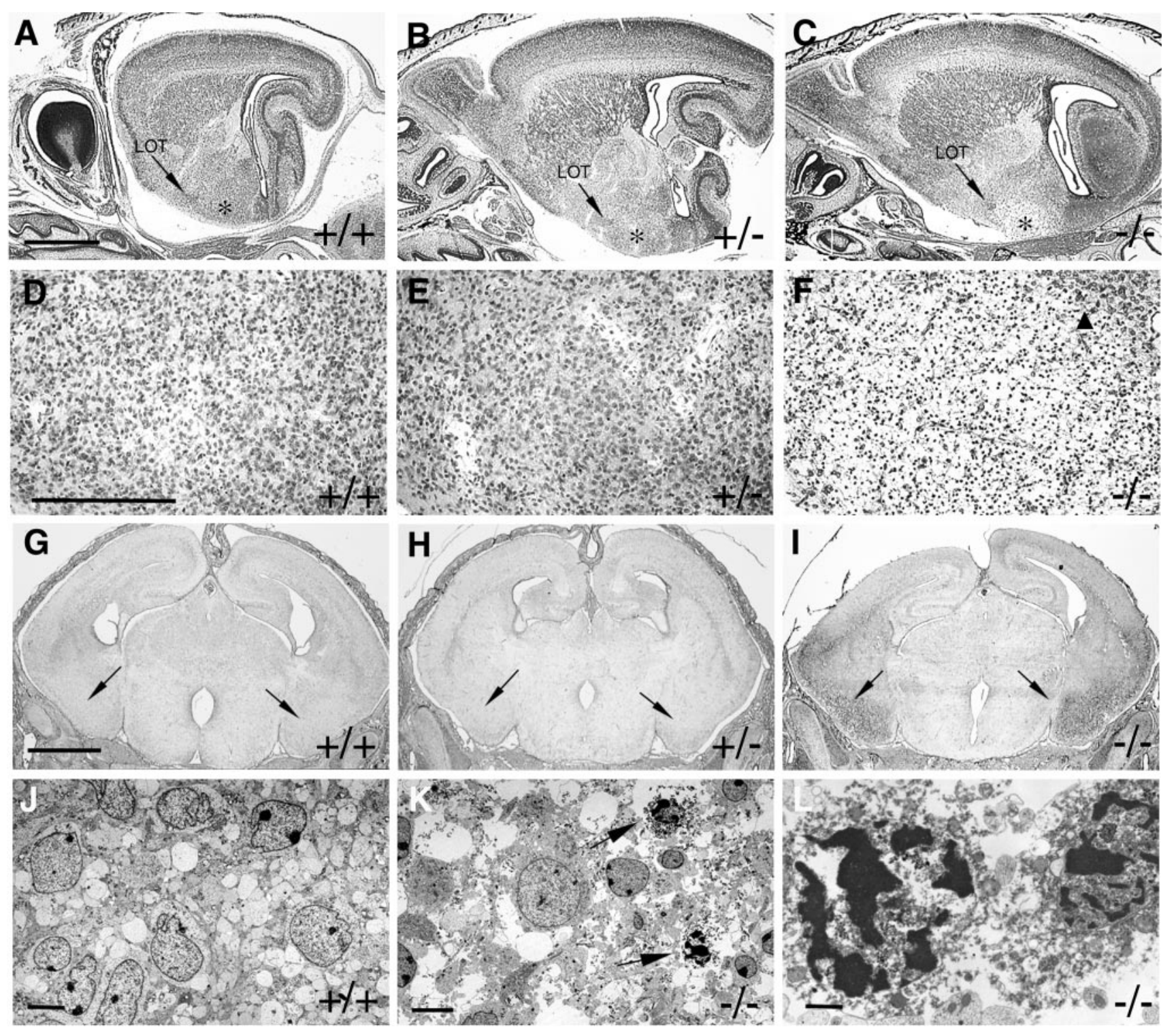

Figure 2. Histopathology of mouse brains defective for the Atp1a2 gene. A-C, Sagittal sections of E18.5-P0 fetal brains of wild-type $(+/+)$, heterozygous $(+/-)$, and homozygous $(-/-)$ mutant mice. Representative photographs are shown from multiple brains analyzed of wild-type $(n=7)$, heterozygous $(n=7)$, and homozygous $(n=13)$ mice. Note the decreased cellular density in the homozygous mice (C) that is limited to the amygdala (asterisks), with the exception of the nucleus of the lateral olfactory tract (LOT). Scalebar, $1 \mathrm{~mm} . D-F$, Higher magnification of the amygdala regions shown in $A-C$, respectively. In the homozygous mutant, the decreased cellular density in the amygdala was bordered by regions of normal cellular density (F, arrowheads). Scale bar, $250 \mu \mathrm{m}$. $G-I$, Increased apoptosis in the brain of homozygous mutant mice. Frontal sections of the brain at E18.5-P0 were stained by TUNEL. The numbers of TUNEL-positive cells in the amygdala and piriform cortex (arrows) were higher in the homozygous brain than in the heterozygous or wild-type brains. In the same sections counterstained with Hoechst 33258, the TUNEL-positive cells had pyknotic nuclei (data not shown). Scale bar, 1 mm. $J-L$, Electron micrographs of cells in the amygdala (E18.5-P0). Condensed chromatin ( $K$, arrows) typical of apoptotic cells was observed in the homozygous mutant $(K, L)$ but not in the wild-type ( $)$ or heterozygous mutant (data not shown). Two littermates of the wild-type and three of the homozygous were examined. Scale bars:J, K, $5 \mu \mathrm{m} ; L, 2 \mu \mathrm{m}$.

\section{Statistical analysis}

Data are expressed as mean \pm SEM. Differences between groups were examined for statistical significance using one- or two-way ANOVA followed by Fisher's PLSD test in the experiments shown in Figures $5 A-D, 6$, $C$ and $D$, and $7 H$. Data of behavioral analyses shown in Figure $7 A-G$ were compared by the Student's $t$ test. $p<0.05$ denoted the presence of a statistically significant difference.

\section{Results}

\section{Generation of Atp1a2-deficient mice}

To study the function of the sodium pump $\alpha 2$ subunit during embryonic development and in adult mice, we generated mice with a mutant $\alpha 2$ subunit gene (Fig. 1). A neomycin-resistant gene cassette (neo) was inserted in exon 21, and the targeted allele was verified by PCR (data not shown) and Southern hybridization (Fig. 1B). We confirmed the lack of $\alpha 2$ subunit mRNA in the brain and lack of the protein in microsomal fractions of the brain prepared from homozygous E18.5 embryos (Fig. 1C,D). The homozygous mutant mice survived until birth but died soon after. No gross morphological defects were observed in the homozygous embryos, and there were no apparent histological anomalies in either skeletal or heart muscle (data not shown). The E18.5 embryos showed no spontaneous movement and lacked a nociceptive response, but diaphragmatic muscle contraction was observed when the phrenic nerve was stimulated (data not shown), and we did not observe any significant differences of the resting membrane potential of the diaphragm muscle fibers [wild type: $-65.4 \pm 1.9 \mathrm{mV}(n=4)$; heterozygote: $-65.7 \pm 2.8 \mathrm{mV}(n=5)$; homozygote, $-63.9 \pm 2.2 \mathrm{mV}(n=4)]$. Therefore, we focused our analyses on the CNS. 
Table 1. Histopathological analysis of E18.5-P0 embryo brains

\begin{tabular}{|c|c|c|c|}
\hline \multirow{2}{*}{$\begin{array}{l}\text { Atp1a2 } \\
\text { genotype }\end{array}$} & \multicolumn{2}{|c|}{ Number of degenerated cells } & \multirow{2}{*}{$\begin{array}{l}\text { TUNEL positive/number of } \\
\text { litters examined by TUNEL }\end{array}$} \\
\hline & Amygdala $^{a}$ & Piriform cortex ${ }^{a}$ & \\
\hline$+1+$ & $\begin{array}{l}13.3 \pm 2.3 \\
(9.2 \pm 1.6 \%)\end{array}$ & $\begin{array}{l}17.5 \pm 4.0 \\
(9.6 \pm 2.1 \%)\end{array}$ & $0 / 2$ \\
\hline$+1-$ & $\begin{array}{l}10.3 \pm 1.1 \\
(6.3 \pm 0.6 \%)\end{array}$ & $\begin{array}{l}13.8 \pm 3.3 \\
(7.6 \pm 1.5 \%)\end{array}$ & $0 / 2$ \\
\hline$-1-$ & $\begin{array}{c}86.8 \pm 11.5^{*} \\
(73.3 \pm 7.0 \%)^{*}\end{array}$ & $\begin{array}{l}111.0 \pm 10.8^{*} \\
(86.3 \pm 3.6 \%)^{*}\end{array}$ & $2 / 2$ \\
\hline
\end{tabular}

${ }^{a}$ Degenerating cells were counted in a $0.029 \mathrm{~mm}^{2}$ square of the amygdaloid region or piriform cortex on three successive frontal sections ( $10 \mu \mathrm{m}$ thick) at the level of the supraoptic nucleus in each mouse. The mean number of the three sections was obtained as degenerating cells per mouse. We examined four mice $(n=4)$ in each genotype, and the mean number of degenerating cells \pm SEM is shown. In the parentheses, percentages of the number of degenerating cells out of the total number of cells \pm SEM in the area are shown. Cells that have pyknotic nuclear changes and/or eosinophilic staining of the cytoplasm were defined as degenerating cells. ${ }^{*} p<0.001$, compared with the wild types and heterozygotes.

${ }^{b}$ Data represent number of embryos.

\section{Apoptosis of neurons in the amygdala and piriform cortex in the homozygous mutant embryos}

Histological examination of the homozygous brain at E18.5postnatal day 0 ( $\mathrm{P} 0)$ showed extensive neuronal cell loss in the amygdala and piriform cortex (Fig. 2C,F, Table 1), and abundant apoptotic neurons were found in these regions as determined by TUNEL (Fig. 2G-I) and electron microscopy (Fig. $2 J-L$ ). At this stage, the entire amygdaloid complex, including "the basolateral complex" and "the central and medial division" (Valverde, 1965), was severely damaged in the homozygous mice, whereas the nucleus of the lateral olfactory tract was spared (Fig. 2C). The hippocampal and cingulate cortices also appeared to be unaffected (Fig. 2G-I) (data not shown). The degenerative changes in the amygdala and piriform cortex could be detected as early as E17.5-18 in the homozygous embryos (data not shown). To our knowledge, selective damage of the amygdala and piriform cortex has not been reported previously in any other gene disruption study in mice. Therefore, our result suggests a specific role of the $\alpha 2$ subunit in the survival of this set of neurons late in embryogenesis.

We reasoned that the selective degeneration of this subset of neurons might reflect a restricted expression pattern of the $\alpha 2$ subunit in this region. To test this possibility, we examined the distribution of the $\alpha 2$ subunit in the brain of wild-type E17.5 embryos by immunostaining. The use of affinity-purified peptide antibody against the $\mathrm{N}$-terminal portion specific to the $\alpha 2$ subunit showed strong staining in the meninges, where the $\alpha 2$ subunit mRNA has been reported to be abundant (Fig. 3B, arrowheads) (Herrera et al., 1994). In the brain, the $\alpha 2$ subunit was distributed throughout the cerebral cortex and subcortical nuclear regions, including the piriform cortex and amygdala (Fig. $3 B$ ). The $\alpha 2$ subunit was detected in neuronal cell bodies and in the neuropil (a mixture of neuronal and glial cell processes) in the amygdala (Fig. 3D) and piriform cortex (Fig. 3F), as well as other regions of the cerebral cortex and subcortical nuclear regions (data not shown), indicating that the $\alpha 2$ subunit resides in both neuronal and glial cells. These results are consistent with the report that the $\alpha 2$ subunit is expressed in neurons and glia throughout the brain of E18.5 embryo (Moseley et al., 2002). We conclude that the selective degeneration of this region is not caused by the restricted distribution of the $\alpha 2$ subunit.

\section{Overexpression of c-Fos in the amygdala and piriform cortex in the homozygous mutant embryos}

Excitatory amino acids, such as glutamic acid, are known to become "excitotoxins" when their concentration in the extracellu-

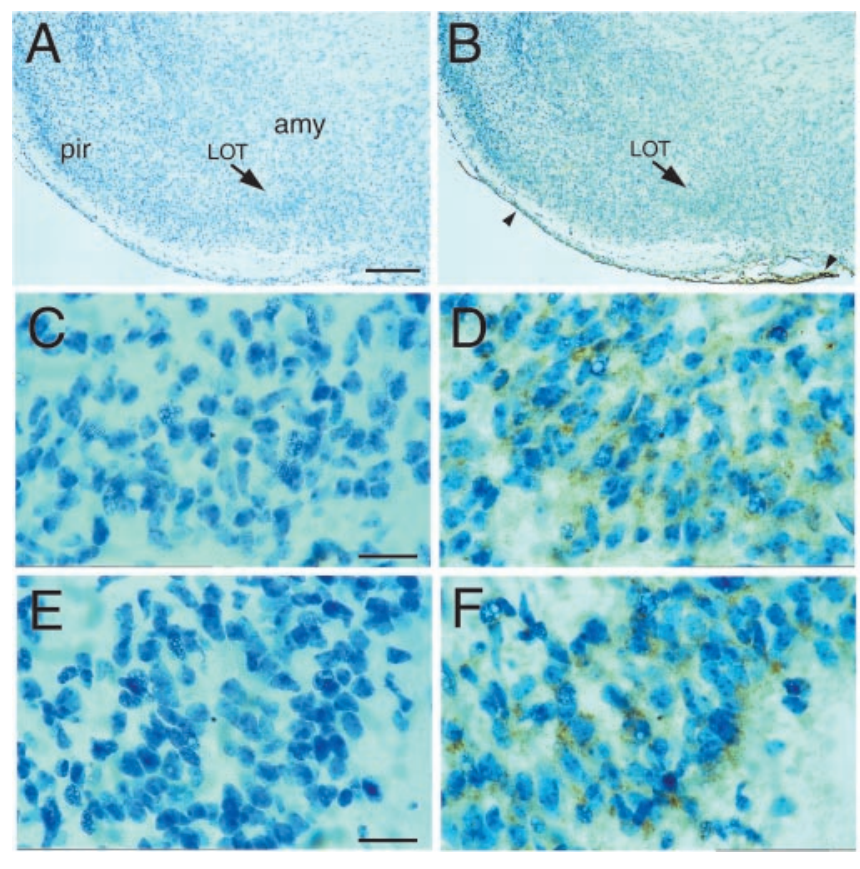

Figure 3. Photomicrographs showing the expression of the $\alpha 2$ subunit in the amygdala and piriform cortex of wild-type E17.5 embryos. Immunoreactive cells using an affinity-purified $\alpha 2$ subunit peptide antibody $(B, D, F)$ and a control $\lg G(A, C, E)$ are shown. Sections of embryonic mouse brain $(C 57 \mathrm{BL} / 6 \mathrm{~J})$ at lower magnification $(A, B)$ and higher magnification $(C-F)$ of the amygdala $(C, D)$ and the piriform cortex $(E, F)$. The reddish-brown colored reaction product is observed in the meninges ( $B$, arrowheads) and distributed throughout the cerebral cortex and subcortical nuclear regions $(B)$. The product is detected in neuronal cell bodies and in the neuropil $(D, F)$. Note that some neuronal cells do not show immunoreaction with the $\alpha 2$ subunit antibody $(D, F)$. All sections were counterstained with hematoxylin. amy, Amygdala; pir, piriform cortex; LOT, nucleus of the lateral olfactory tract. Frontal sections are shown. Scale bars: $A, B, 200 \mu \mathrm{m} ; C-F, 20 \mu \mathrm{m}$.

lar space of the brain is high (for review, see Rothman and Olney, 1987; Coyle and Puttfarcken, 1993). Disruption of the $\alpha 2$ subunit might alter the transport or re-uptake of excitatory amino acids; therefore, it is plausible that the selective damage in the homozygote might reflect toxicity from spontaneous neural activity during embryonic development. To test this hypothesis, we examined neural activity by c-Fos immunostaining (Hunt et al., 1987). In the wild-type embryos at E17.5-18.5, c-Fos-positive cells were detected in the amygdala and piriform cortex but not in the hippocampus, neocortex, or cerebellar cortex (Fig. 4A, Table 2) (data not shown), indicating spontaneous neural activity in the amygdala and piriform cortex at this embryonic stage. A significantly higher number of c-Fos-positive cells were found in the amygdala and piriform cortex in the homozygous mutant embryos compared with the wild-type and heterozygous embryos (Fig. 4A-C, Table 2). Furthermore, both c-Fos-positive cells and degenerating neurons were observed in these regions of the homozygous brains just before birth (Fig. $4 D-I$ ). These observations suggest enhanced neural activity in the amygdala and piriform cortex of the homozygous mutants and suggest that excitotoxic damage causes the neural degeneration in these specific regions.

Impaired uptake of neurotransmitters into $\mathrm{P}_{2}$ fraction of the homozygous mutants

Glutamic acid and GABA are the principal neurotransmitters in the amygdala (Davis et al., 1994). At E17.5-18.0, the whole-brain levels of both neurotransmitters were higher in the homozygous 


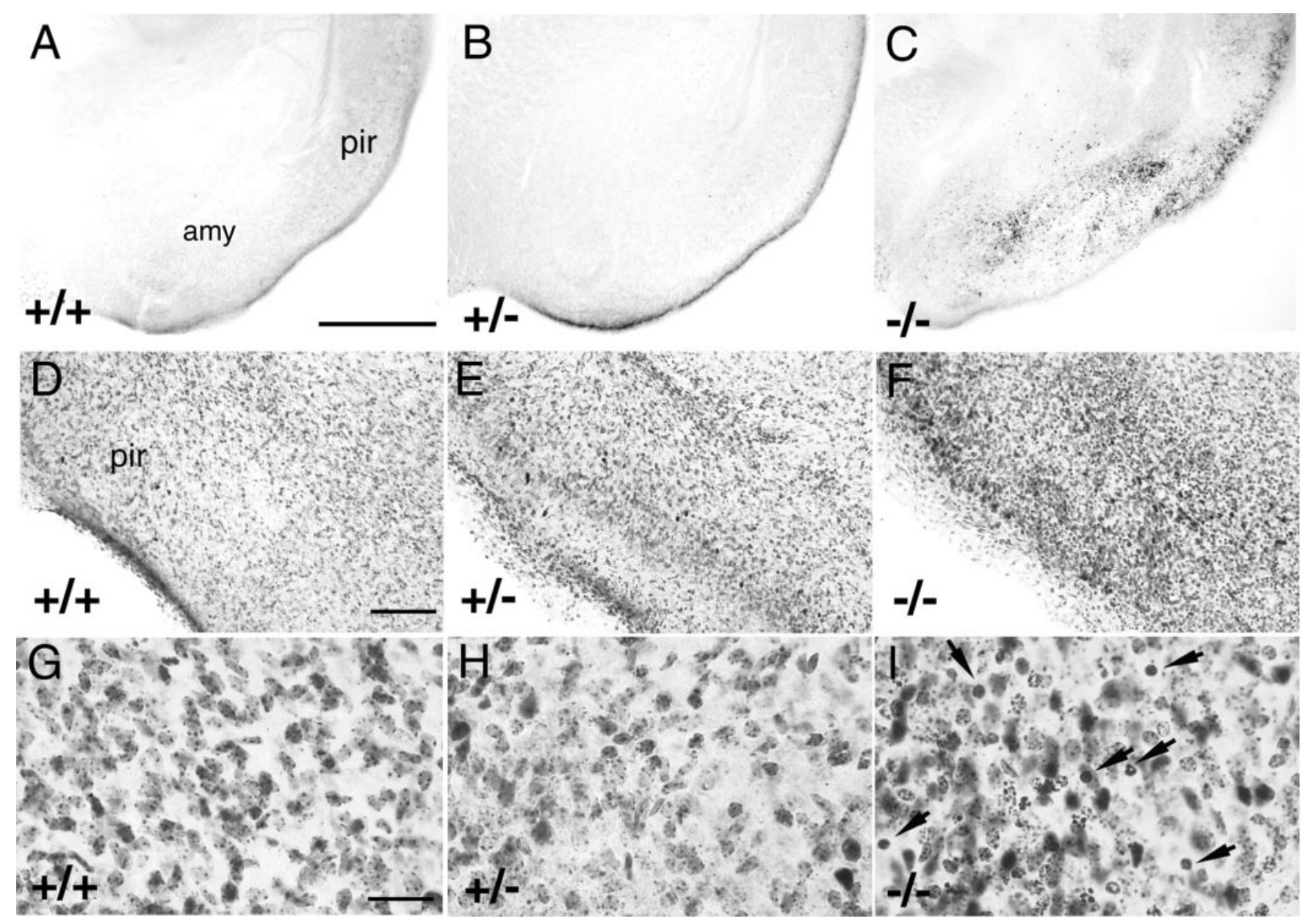

Figure 4. Augmented c-Fos expression and increased numbers of degenerating cells in the amygdala and piriform cortex of homozygous mutant mouse embryos. Production of c-Fos protein was detected by immunostaining with an anti-C-Fos antibody (indicated as black dots). $A-C$, Representative photographs are shown from five sets of E17.5-18.5 littermates: a wild-type embryo ( $A$ ), a heterozygous embryo ( $B)$, and a homozygous embryo ( ( ). Scale bar, $500 \mu \mathrm{m} . D-F, c-$ Fos-immunostained sections are counterstained with cresyl violet. Several c-Fos-positive cells were observed in the amygdala and piriform cortex of the wild-type and heterozygous mice (black dots), but few degenerating cells $(D, E)$ were noted. $F$, Mixed pattern of c-Fos-positive cells and degenerating cells seen in the homozygous mutants. Representative photographs are shown from three sets of embryos just before birth. $G-I$, Higher magnification of $D-F$, respectively. I, $c-$ Fos-positive cells (their nuclei are stained dark gray) and degenerating cells (pyknotic nuclei are stained round black, indicated by arrows) in the homozygous mutants. Frontal sections are shown. Scale bars: $D-F$, $100 \mu \mathrm{m}$; $G-I, 25 \mu \mathrm{m}$. amy, Amygdala; pir, piriform cortex.

Table 2. Number of c-Fos-positive cells in E17.5-18.5 embryo brains

\begin{tabular}{lll}
\hline \multirow{2}{*}{$\begin{array}{l}\text { Atp1a2 } \\
\text { genotype }\end{array}$} & \multicolumn{2}{c}{ Number of c-Fos-positive cells } \\
\cline { 2 - 3 } Amygdala $^{a}$ & Piriform cortex $^{a}$ \\
\hline$+I+$ & $10.1 \pm 3.3$ & $24.0 \pm 8.5$ \\
& $(n=6)$ & $(n=6)$ \\
$+/-$ & $9.5 \pm 3.6$ & $19.3 \pm 5.8$ \\
& $(n=6)$ & $(n=7)$ \\
$-I-$ & $119.6 \pm 27.6^{*}$ & $122.1 \pm 28.5^{*}$ \\
& $(n=8)$ & $(n=8)$ \\
\hline
\end{tabular}

${ }^{a}$ The number of c-Fos-positive cells was counted in an oval region $\left(0.5 \mathrm{~mm}^{2}\right)$ for the amygdala and in an oval region $\left(0.15 \mathrm{~mm}^{2}\right)$ for the piriform cortex. Positive cells were counted on three successive frontal sections (40 $\mu \mathrm{m}$ thick) at the level of the supraoptic nucleus in each mouse. The mean number of the three sections was obtained as c-Fospositive cells per mouse. The numbers of mice examined are in parentheses. The mean numbers of c-Fos-positive cells \pm SEM are shown. ${ }^{*} p<0.002$, compared with the wild type and heterozygotes.

mutants than in heterozygous or wild-type mice (Fig. 5A,B). A transporter specific to each neurotransmitter mediates its uptake into nerve terminals and adjacent glial cells, maintaining the extracellular neurotransmitter concentrations at low levels in the CNS (Borden, 1996; Danbolt, 2001). $\mathrm{Na}^{+}, \mathrm{K}^{+}$-ATPase generates a sodium gradient used by the transporters to drive the "uphill" transport of the neurotransmitters (Kanner and Schuldiner,
1987). Because the $\alpha 2$ subunit was expressed both in glial cells and in neurons (Fig. 3), we investigated whether the $\alpha 2$ subunit is involved in the neurotransmitter uptake by astrocytes and/or nerve terminals.

First, we examined the uptake of the neurotransmitters into $\mathrm{P}_{2}$ fraction, which contains nerve-ending particles, prepared from whole embryonic brain at E16.5-17.5, when severe apoptosis had not yet occurred in the amygdala and piriform cortex of the homozygous mutant. To perform uptake assays, it was necessary to use fresh samples from each fetal brain before confirming the genotype. It was difficult to isolate a sufficient amount of an enriched synaptosomal fraction from a single embryonic brain by using a Ficoll or Percoll gradient centrifugation method; thus we used a $\mathrm{P}_{2}$ fraction in the following experiments. The $\mathrm{P}_{2}$ fraction of homozygous mutant mice showed lower neurotransmitter uptake activity for both glutamic acid and GABA ( 69 and $68 \%$ of the wild type, respectively) [Fig. $5 C$, columns $1,3,5(n=5) ; D$, columns 1, 3, $5(n=6)]$. These uptake activities were inhibited $21-29 \%$ by ouabain in wild-type and heterozygous mutant samples (compare columns 1 and 2 and columns 3 and 4 ). On the contrary, the neurotransmitter uptake of the homozygous mutant was not significantly inhibited by ouabain (compare 
A

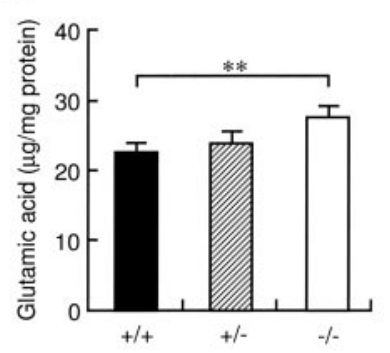

C

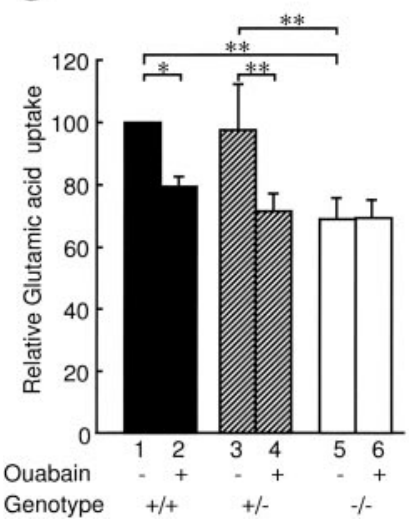

B

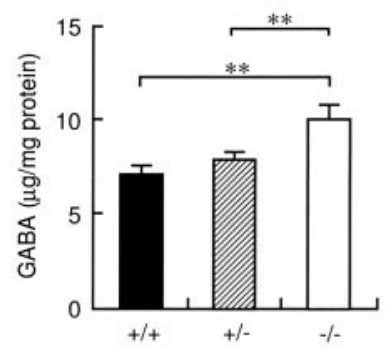

D

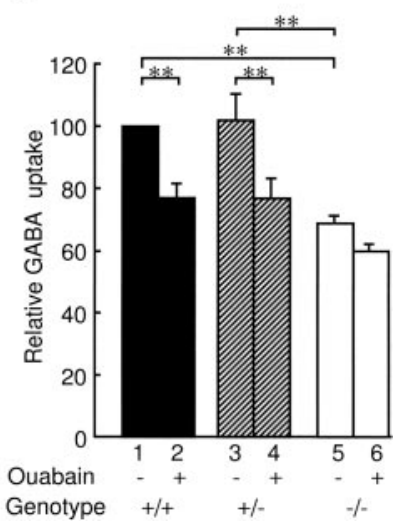

A

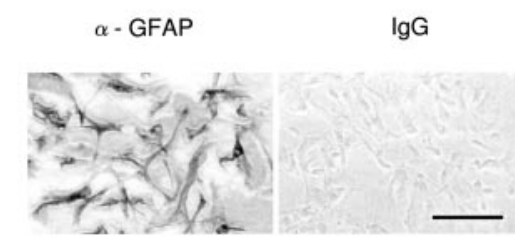

B

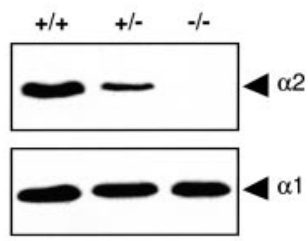

C

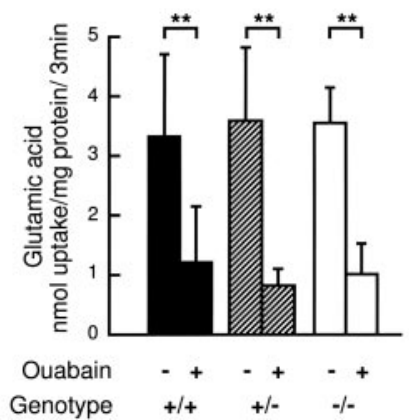

D

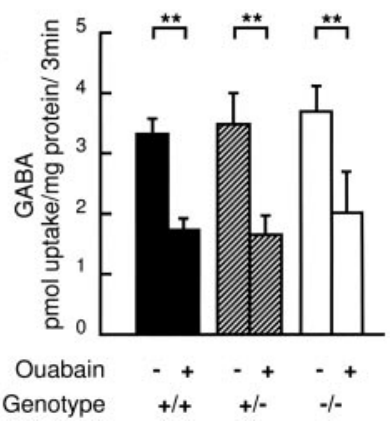

Figure 6. Glutamic acid and GABA uptake in cultured astrocytes prepared from wild-type, heterozygous, and homozygous mice. $A$, Representative immunostaining of GFAP or control lgG in cultured astrocytes prepared from a homozygous mutant used in these assays. Phasecontrast images are shown. Scale bar, $100 \mu \mathrm{m}$. B, Immunoblot showing the amount of the $\alpha 2$ subunit and the $\alpha 1$ subunit in microsomal fractions prepared from cultured astrocytes from wild-type $(+/+)$, heterozygous $(+/-)$, and homozygous $(-/-)$ mice. $C$, $D$, Specific uptake of $\left[{ }^{3} \mathrm{H}\right]$ glutamic acid and $\left[{ }^{3} \mathrm{H}\right] \mathrm{GABA}$ into astrocytes in a 3 min incubation at $26^{\circ} \mathrm{C}$, for which period specific uptake was correlated linearly with incubation time. The specific uptake activity was almost the same among wild-type, heterozygous, and homozygous mice and in each case was significantly inhibited by the addition of $1 \mathrm{~mm}$ ouabain. Error bars indicate SEM. ${ }^{* *} p<0.01$.

was significantly inhibited by ouabain in all of the genotypes (Fig. $6 C, D)$. Together, these results demonstrate that the ouabainsensitive uptake of neurotransmitters by glial cells was not dependent on the $\alpha 2$ subunit, whereas this uptake by the $\mathrm{P}_{2}$ fraction containing both neuronal and glial elements was partly dependent on the $\alpha 2$ subunit. We therefore conclude that the uptake of glutamic acid and GABA by neuronal terminals is impaired in the homozygous mutant, although we cannot entirely rule out the involvement of glial cells.

\section{Enhanced fear and anxiety behavior in the heterozygous mutant}

The amygdala and temporal lobe structures have critical roles in emotional behavior (Swanson and Petrovich, 1998; Fendt and Fanselow, 1999; LeDoux, 2000; Maren, 2001; Davis, 2002). Although we could not document significant cell loss in these regions in the heterozygous mutant brains (data not shown), we hypothesized that there might be a functional anomaly. Accordingly, we investigated the heterozygous mice for behavioral and neural activities. We performed the light/dark test (Fig. 7A-D) ( $n=11$ for each genotype), open field test (Fig. $7 E)(n=16$ for each genotype), and elevated-plus maze test (Fig. $7 F, G)(n=11$ for each genotype) using adult male heterozygous mice and their wild-type littermate controls. In all of these tests, the heterozygous mutant mice showed increased fear/anxiety behaviors compared with the wild-type mice. In contrast, general locomotion activity, as measured by home-cage activity monitoring (Table 3, left column), and motor coordination, as measured by rota-rod 
testing (Table 3, right column), were not significantly different between the heterozygous and wild-type mice.

Finally, we investigated their response to conditioned fear stimuli $(n=8$ for each genotype and treatment). The heterozygous mutant mice showed exaggerated freezing behaviors (Fig. $7 H$ ) compared with the wild-type mice after conditioned fear stimuli. These results strongly suggest that the heterozygous mutant mice have a functional anomaly in the amygdala and piriform cortex. To determine whether neural activity in the amygdala or piriform cortex was abnormally increased in the heterozygous mutant mice under conditioned fear stimuli, we examined c-Fos expression in these regions. After conditioned fear stimulus, the numbers of c-Fos-positive cells in the amygdala and piriform cortex were higher in the heterozygous mutant mice than in wild-type mice (Fig. $8 A, B$ ). In contrast, few c-Fospositive cells were found in the amygdala and piriform cortex in the heterozygous or wild-type mice kept in the home cages (Fig. $8 C, D$ ). These results indicate that the heterozygous mutant mice have abnormally enhanced neural activity in response to conditions that induce fear or anxiety.
A
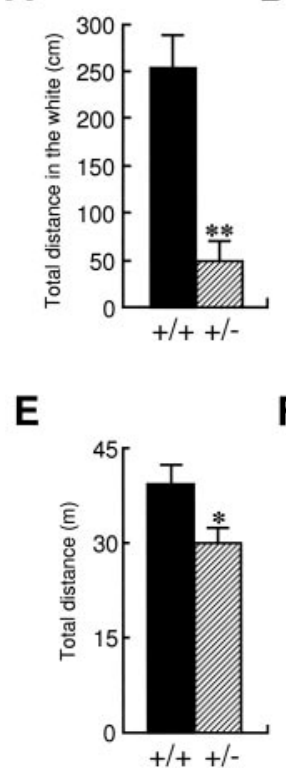

B

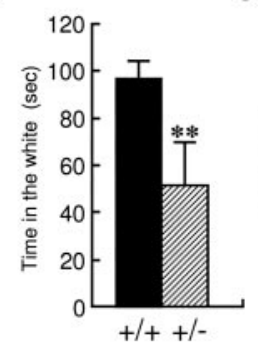

$\mathbf{F}$

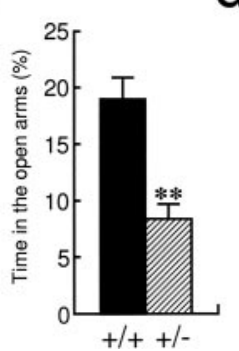

C

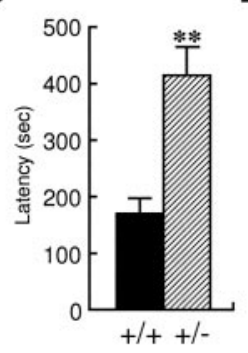

D

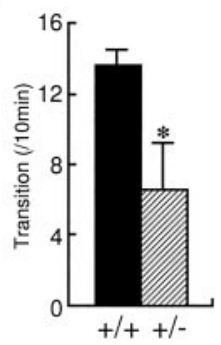

Figure 7. Enhanced anxiety-like behaviors in heterozygous adult mice. $A-D$, Light/dark test. $A$, Total path length in the light compartment (white) in the light/dark test. $B$, Total length of time spent in the light compartment of the light/dark test. $C$, Latency to first entry to the light compartment in the light/dark test. $D$, Number of transitions between the light and dark compartments in the light/dark test. $A-D, n=11$ for each genotype. $E$, Total path length in the open-field test ( $n=16$ for each genotype). $F, G$, Elevated-plus maze. F, Percentage of time in the open arms of the elevated-plus maze. $G$, Percentage entries into the open arms of the elevated-plus maze. $F, G, n=11$ for each genotype. $H$, Freezing time in conditioned fear paradigms $(n=8$ for each genotype and treatment). C, Control mice without foot shock; $F$, mice that received foot shock during conditioning. Solid bar represents wild-type mice; hatched bar represents heterozygous mice. Error bars indicate SEM. NS, Not significant. ${ }^{*} p<0.05$; ${ }^{* *} p<0.01$
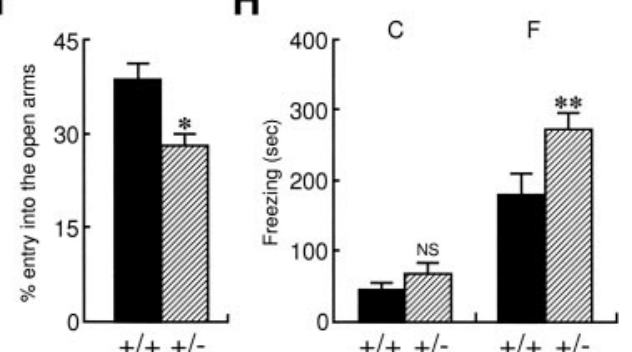

\section{Discussion}

\section{Selective damage of the amygdala and piriform cortex in} Atp1a2 mutant mice

Maintenance of a membrane potential in electrically excitable cells is dependent on $\mathrm{Na}^{+}$and $\mathrm{K}^{+}$gradients that are generated by the sodium pump. Inhibition of $\mathrm{Na}^{+}, \mathrm{K}^{+}$-ATPase enzyme activity by ouabain results in depolarization of neurons and glia. However, a low concentration of ouabain, which supposedly inhibits the activity of $\alpha 2$ and $\alpha 3$ subunits but not $\alpha 1$, does not alter the resting membrane potential in rat brain slices (Calabresi et al., 1995), suggesting alternative roles of $\alpha 2$ and $\alpha 3$ subunits other than the maintenance of the electrochemical gradients of $\mathrm{Na}^{+}$ and $\mathrm{K}^{+}$in brain. In our embryos with a homozygous mutation of the $\alpha 2$ subunit, the uptake of glutamic acid and GABA into the $\mathrm{P}_{2}$ fraction was significantly reduced. Interestingly, ouabain decreased the uptake of these neurotransmitters into the $\mathrm{P}_{2}$ fraction from wild-type and heterozygous mice to the level of the homozygous mutant, suggesting that ouabain-sensitive uptake into the $\mathrm{P}_{2}$ fraction of the embryonic brain is dependent on the $\alpha 2$ subunit. In contrast, cultured astrocytes from homozygous mutant embryos did not show any impairment of neurotransmitter uptake compared with wild-type and heterozygous mutant embryos. Therefore, we propose that the $\alpha 2$ subunit in neurons contributes to the clearance of neurotransmitters at this stage of development. This function is important to protect neurons from the continued activity of neurotransmitters. Figure $4 A-C$ and Table 2 demonstrate the presence of spontaneous neural activity in the amygdala and piriform cortex in wild-type mice before birth and increased neural activity in these regions in the homozygous mutant mice. Although the physiological role of spontaneous neural activity in these regions during normal embryonic development is unknown, accumulation of glutamic acid in the
Table 3. Spontaneous motor activity in the home cage and motor coordination (rota-rod test) of the adult wild-type and heterozygous mice

\begin{tabular}{lll}
\hline $\begin{array}{l}\text { Atp1a2 } \\
\text { genotype }\end{array}$ & $\begin{array}{l}\text { Spontaneous activity } \\
\text { (counts/2 d) }\end{array}$ & Rota-rod (sec) \\
\hline$+/+$ & $10826 \pm 1392^{a}$ & $285.7 \pm 24.1^{a}$ \\
& $(n=7)$ & $(n=6)$ \\
$+/-$ & $14809 \pm 2708^{a}$ & $296.0 \pm 24.4^{a}$ \\
& $(n=7)$ & $(n=8)$ \\
\hline
\end{tabular}

${ }^{a}$ There is no significant difference between the wild-type and the heterozygous adult male mice. The numbers of the mice examined are in parentheses. Data are means \pm SEM.

extracellular space may induce neural hyperactivity and eventually result in neuronal apoptosis (Choi, 1988; Coyle and Puttfarcken, 1993). GABA also acts as an excitatory neurotransmitter during embryonic development, and GABAmediated excitation can trigger $\mathrm{Ca}^{2+}$ influx (Ganguly et al., 2001). In addition, the amygdala and piriform cortex are reported to be vulnerable to excitotoxicity (Candelario-Jalil et al., 2001). Accordingly, decreased neurotransmitter uptake in the homozygous mutant mice might enhance spontaneous neural activity and cause excitotoxic neuronal apoptosis, leading to selective damage of these regions. Neuronal cell death in the amygdala and piriform cortex, however, may not be the direct cause of lethality in the homozygous mutant mice. Very recently, another mutation of the $\alpha 2$ subunit was established in mice by a different targeting strategy, and these mice are reported to have a respiratory defect caused by a CNS impairment (Moseley et al., 2002). It may be possible that our homozygous mutant mice also die because of defects in the regulation of the respiratory circuits in the brain. 


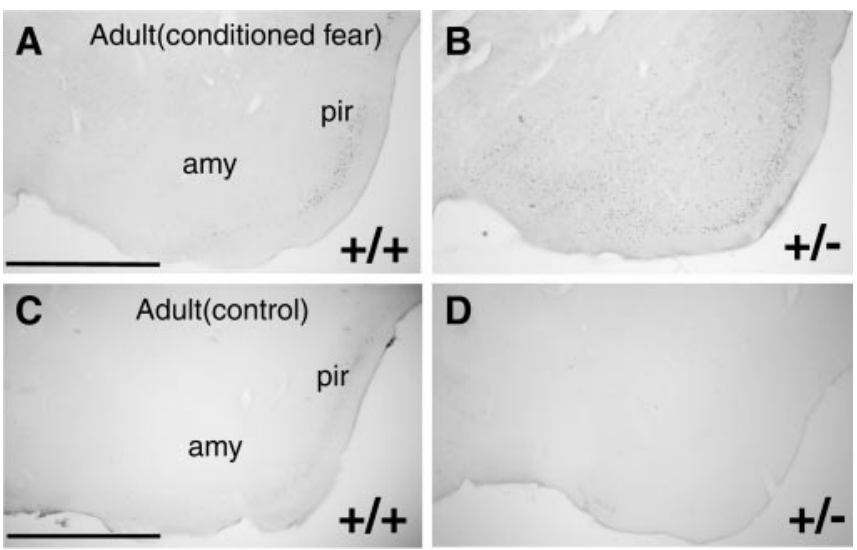

Figure 8. Increased c-Fos expression in adult male heterozygous mutant mice under conditioned fear stimuli. Production of c-Fos protein was detected by an anti-c-Fos antibody and appears as black spots in the expressing nuclei. $A, B$, Representative photographs are shown from four sets of trials for each genotype under conditioned fear stimuli for wild-type $(A)$ and heterozygous $(B)$ mice. The mean numbers of c-Fos-positive cells were 95 per section $(+/+)$ and 449 per section $(+/-)$ for the piriform cortex and 120 per section $(+/+)$ and $399(+/-)$ for the amygdala. $C, D$, Little c-Fos expression was detected in these regions of the adult brain in either genotype when mice were kept in their home cages. The mean number of c-Fos-positive cells was 23 per section $(+/+)$ and 20 per section $(+/-)$ for the piriform cortex and 19 per section $(+/+)$ and $31(+/-)$ for the amygdala. Representative photographs are shown from four sets of each genotype in its home cage. The amygdala (amy) and piriform cortex (pir) are indicated. Scale bar, $1 \mathrm{~mm}$.

\section{Impaired uptake of glutamic acid and GABA into $P_{2}$ fraction of homozygous mutant mice}

Re-uptake of neurotransmitters, such as glutamic acid and GABA, is known to occur through their respective transporters. A functional link between the $\mathrm{Na}^{+}, \mathrm{K}^{+}$-ATPase and such transporters has been suggested by ouabain inhibition experiments (Kanner and Schuldiner, 1987; Wonnemann et al., 2000). Reduced uptake of glutamic acid and GABA into the $\mathrm{P}_{2}$ fraction in our homozygous mutant mice indicates that the $\alpha 2$ subunit of the $\mathrm{Na}^{+}, \mathrm{K}^{+}$-ATPase is partially responsible for the re-uptake process. The active transport of $\mathrm{Na}^{+}$and $\mathrm{K}^{+}$in the resting membrane is mediated by the $\alpha 1$ subunit. The $\alpha 2$ subunit shows lower affinity for $\mathrm{K}^{+}$than $\alpha 1$ (Blanco et al., 1995) and functions less efficiently in the resting condition. During neural excitation, however, the $\alpha 2$ subunit is activated by the higher $\mathrm{K}^{+}$concentration in the extracellular space. Therefore, the contribution of the $\alpha 2$ subunit to neurotransmitter re-uptake could be critical during neuronal activity. The functional coupling between the $\alpha 2$ subunit and transporters would be facilitated if the $\alpha 2$ subunit resides in close proximity with the neurotransmitter transporters. In this context, the model has been proposed that the colocalization of the $\alpha 2$ subunit and the $\mathrm{Na}^{+} / \mathrm{Ca}^{2+}$ exchanger allows an $\alpha 2$ isoform-specific function in the regulation of intracellular $\mathrm{Ca}^{2+}$ concentrations and cardiac contractility (Juhaszova and Blaustein, 1997; James et al., 1999). Although colocalization of the $\alpha 2$ subunit and amino acid transporters remains to be examined, the specific functions of the $\alpha 2$ subunit might be based on structural and functional coupling with $\mathrm{Na}^{+}$-dependent transporters.

\section{Enhanced fear/anxiety behaviors in heterozygous mutant mice}

The heterozygous mutant mice did not have any apparent anatomical anomaly or enhanced neuronal degeneration in the amygdala and piriform cortex during embryonic development
(Figs. 2, 4) or in the adult (data not shown). However, the heterozygous mutant mice had enhanced fear/anxiety behaviors and increased c-Fos expression in the amygdala and piriform cortex after conditioned fear stimuli. Electrical or chemical stimulation of the amygdala produces a pattern of behavioral and autonomic changes that resembles a state of fear (Davis, 2002). Thus, neuronal hyperactivity in these regions of the heterozygous mice may be a cause of the increased fear/anxiety behavior. In this regard, it is interesting that decreased expression of the $\alpha 2$ subunit was reported in the temporal cortex of bipolar patients (Rose et al., 1998). The enhanced fear/anxiety behaviors of our adult heterozygous mutant mice could provide clues to the pathophysiology of human affective disorders. In conclusion, our mutation of the Atpla 2 gene in mice reveals, for the first time, the functional significance of the $\alpha 2$ subunit in the development of the amygdala and piriform cortex and in emotional behaviors in adult.

\section{References}

Blanco G, Koster JC, Sánchez G, Mercer RW (1995) Kinetic properties of the $\alpha 2 \beta 1$ and $\alpha 2 \beta 2$ isozymes of the Na,K-ATPase. Biochemistry 34:319-325.

Borden LA (1996) GABA transporter heterogeneity: pharmacology and cellular localization. Neurochem Int 29:335-356.

Calabresi P, De Murtas M, Pisani A, Stefani A, Sancesario G, Mercuri NB, Bernardi G (1995) Vulnerability of medium spiny striatal neurons to glutamate: role of $\mathrm{Na}^{+} / \mathrm{K}^{+}$ATPase. Eur J Neurosci 7:1674-1683.

Candelario-Jalil E, Al-Dalain SM, Castillo R, Martinez G, Fernandez OSL (2001) Selective vulnerability to kainate-induced oxidative damage in different rat brain regions. J Appl Toxicol 21:403-407.

Choi DW (1988) Glutamate neurotoxicity and diseases of the nervous system. Neuron 1:623-634.

Coyle JT, Puttfarcken P (1993) Oxidative stress, glutamate, and neurodegenerative disorders. Science 262:689-695.

Danbolt NC (2001) Glutamate uptake. Prog Neurobiol 65:1-105.

Davis M (2002) Neural circuitry of anxiety and stress disorders. In: Neuropsychopharmacology: the fifth generation of progress (Davis KL, Charney D, Coyle JT, Nemeroff C, eds), pp 931-951. Philadelphia: Lippincott Williams \& Wilkins.

Davis M, Rainnie D, Cassell M (1994) Neurotransmission in the rat amygdala related to fear and anxiety. Trends Neurosci 17:208-214.

Fendt M, Fanselow MS (1999) The neuroanatomical and neurochemical basis of conditioned fear. Neurosci Biobehav Rev 23:743-760.

Ganguly K, Schinder AF, Wong ST, Poo M (2001) GABA itself promotes the developmental switch of neuronal GABAergic responses from excitation to inhibition. Cell 105:521-532.

Geering K (2001) The functional role of $\beta$ subunits in oligomeric P-type ATPases. J Bioenerg Biomembr 33:425-438.

Gray EG, Whittaker VP (1962) The isolation of nerve endings from brain: an electron-microscopic study of cell fragments derived by homogenization and centrifugation. J Anat (Lond) 96:79-87.

Guillaume D, Grisar T, Delgado-Escueta AV, Minet A, Vergniolle-Burette M, Bureau-Heeren M (1989) Phenytoin dephosphorylates the alpha(-) catalytic subunit of $\left(\mathrm{Na}^{+}, \mathrm{K}^{+}\right)$-ATPase. A study in mouse, cat and human brain. Biochem Pharmacol 38:3933-3939.

Hanaichi T, Sato T, Iwamoto T, Malavasi-Yamashiro J, Hoshino M, Mizuno N (1986) A stable lead by modification of Sato's method. J Electron Microsc (Tokyo) 35:304-306.

Hara Y, Urayama O, Kawakami K, Nojima H, Nagamune H, Kojima T, Ohta T, Nagano K, Nakao M (1987) Primary structures of two types of alphasubunit of rat brain $\mathrm{Na}^{+}, \mathrm{K}^{+}$-ATPase deduced from cDNA sequences. J Biochem (Tokyo) 102:43-58.

Herrera VLM, Cova T, Sassoon D, Ruiz-Opazo N (1994) Developmental cell-specific regulation of $\mathrm{Na}^{+}-\mathrm{K}^{+}$-ATPase $\alpha 1-, \alpha 2-$, and $\alpha 3$-isoform gene expression. Am J Physiol 266:C1301-C1312.

Hunt SP, Pini A, Evan G (1987) Induction of c-fos-like protein in spinal cord neurons following sensory stimulation. Nature 328:632-634.

James PF, Grupp IL, Grupp G, Woo AL, Askew GR, Croyle ML, Walsh RA, Lingrel JB (1999) Identification of a specific role for the Na,K-ATPase $\alpha 2$ isoform as a regulator of calcium in the heart. Mol Cell 3:555-563. 
Juhaszova M, Blaustein MP (1997) $\mathrm{Na}^{+}$pump low and high ouabain affinity $\alpha$ subunit isoforms are differently distributed in cells. Proc Natl Acad Sci USA 94:1800-1805.

Jursky F, Nelson N (1996) Developmental expression of GABA transporters GAT1 and GAT4 suggests involvement in brain maturation. J Neurochem 67:857-867.

Kanerva L, Hervonen A, Tissari AH (1978) Ultrastructure of synaptosomes from fetal rat brain. Acta Physiol Scand 102:50-63.

Kanner BI, Schuldiner S (1987) Mechanism of transport and storage of neurotransmitters. CRC Crit Rev Biochem 22:1-38.

Kawakami K, Watanabe Y, Araki M, Nagano K (1993) Sp1 binds to the adhesion molecule on glia regulatory element that functions as a positive transcription regulatory element in astrocytes. J Neurosci Res $35: 138-146$.

LeDoux JE (2000) Emotion circuits in the brain. Annu Rev Neurosci 23:155-184.

Leng G, Brown CH, Bull PM, Brown D, Scullion S, Currie J, BlackburnMunro RE, Feng J, Onaka T, Verbalis JG, Russell JA, Ludwig M (2001) Responses of magnocellular neurons to osmotic stimulation involves coactivation of excitatory and inhibitory input: an experimental and theoretical analysis. J Neurosci 21:6967-6977.

Lingrel JB, Kuntzweiler $\mathrm{T}$ (1994) $\mathrm{Na}^{+}, \mathrm{K}^{+}$-ATPase. J Biol Chem 269:19659-19662.

Lingrel JB, Orlowski J, Shull MM, Price EM (1990) Molecular genetics of Na,K-ATPase. Prog Nucleic Acid Res Mol Biol 38:37-89.

Maren S (2001) Neurobiology of Pavlovian fear conditioning. Annu Rev Neurosci 24:897-931.

Moseley AE, Lieske SP, Wetzel RK, James PF, Suiwen H, Boivin GP, Witte DP, Ramirez JM, Sweadner KJ, Lingrel JB (2002) Na,K-ATPase $\alpha 2$ isoform is expressed in neurons and its absence disrupts neuronal activity in newborn mice. J Biol Chem 278:5317-5324.

Onaka T, Yagi K (2001) Involvement of $N$-methyl-D-aspartic acid receptor activation in oxytocin and vasopressin release after osmotic stimuli in rats. J Neuroendocrinol 13:166-174.
Orlowski J, Lingrel JB (1988) Tissue-specific and developmental regulation of rat Na,K-ATPase catalytic $\alpha$ isoform and $\beta$ subunit mRNAs. J Biol Chem 263:10436-10442.

Oshima M, Oshima H, Kitagawa K, Kobayashi M, Itakura C, Taketo M (1995) Loss of Apc heterozygosity and abnormal tissue building in nascent intestinal polyps in mice carrying a truncated $A p c$ gene. Proc Natl Acad Sci USA 92:4482-4486.

Peng L, Arystarkhova E, Sweadner KJ (1998) Plasticity of Na,K-ATPase isoform expression in cultures of flat astrocytes: species differences in gene expression. Glia 24:257-271.

Rose AM, Mellett BJ, Valdes Jr R, Kleinman JE, Herman MM, Li R, ElMallakh RS (1998) Alpha2 isoform of the Na,K-adenosine triphosphatase is reduced in temporal cortex of bipolar individuals. Biol Psychiatry 44:892-897.

Rothman SM, Olney JW (1987) Excitotoxicity and the NMDA receptor. Trends Neurosci 10:299-302.

Shamraj OI, Lingrel JB (1994) A putative fourth $\mathrm{Na}^{+}, \mathrm{K}^{+}$-ATPase $\alpha$-subunit gene is expressed in testis. Proc Natl Acad Sci USA 91:12952-12956.

Shull GE, Greeb J, Lingrel JB (1986) Molecular cloning of three distinct forms of the $\mathrm{Na}^{+}, \mathrm{K}^{+}$-ATPase $\alpha$-subunit from rat brain. Biochemistry 25:8125-8132.

Swanson LW, Petrovich GD (1998) What is the amygdala? Trends Neurosci 21:323-331.

Sweadner KJ (1989) Isozymes of the $\mathrm{Na}^{+} / \mathrm{K}^{+}$-ATPase. Biochim Biophys Acta 988:185-220.

Urayama O, Shutt H, Sweadner KJ (1989) Identification of three isozyme proteins of the catalytic subunit of the Na,K-ATPase in rat brain. J Biol Chem 264:8271-8280.

Valverde F (1965) Studies on the piriform lobe. Oxford, UK: Oxford UP.

Wonnemann M, Singer A, Müller WE (2000) Inhibition of synaptosomal uptake of ${ }^{3} \mathrm{H}$-L-glutamate and ${ }^{3} \mathrm{H}$-GABA by hyperforin, a major constituent of St. John's Wort: the role of amiloride sensitive sodium conductive pathways. Neuropsychopharmacology 23:188-197. 